\title{
PALEO
}

Revue d'archéologie préhistorique

19 | 2007

Spécial table ronde ( 1 ère partie) : Le Gravettien : entités régionales d'une paléoculture européenne, Les Eyzies, juillet 2004

\section{The Gravettian on the Middle Danube}

Le Gravettien du cours moyen du Danube.

Jiří A. Svoboda

\section{(2) OpenEdition}

\section{Journals}

Electronic version

URL: https://journals.openedition.org/paleo/607

DOI: $10.4000 /$ paleo.607

ISSN: $2101-0420$

\section{Publisher}

SAMRA

Printed version

Date of publication: 30 December 2007

Number of pages: $203-220$

ISSN: 1145-3370

\section{Electronic reference}

Jiři A. Svoboda, "The Gravettian on the Middle Danube", PALEO [Online], 19 | 2007, Online since 23 April 2009, connection on 25 June 2021. URL: http://journals.openedition.org/paleo/607 ; DOI: https:// doi.org/10.4000/paleo.607

\section{(c) $\oplus \Theta \Theta$}

PALEO est mis à disposition selon les termes de la licence Creative Commons Attribution - Pas d'Utilisation Commerciale - Pas de Modification 4.0 International. 


\title{
THE GRAVETTIAN ON THE MIDDLE DANUBE
}

\author{
Jiř́ A. Svoboda(1)
}

\begin{abstract}
This paper resumes actual results and current viewpoints on the Gravettian in the Middle Danubian part of Europe. The origin of Gravettian is seen as a more complex process than was thought before, involving an impact of industries with backed blades and bladelets from the eastern Mediterranean (Ahmarian, Lagaman, Dabba, beginning before $40 \mathrm{ky}$ BP). After its establishment in Europe, the Danubian Gravettian is ordered into earlier Pavlovian stage (30-25 ky BP), concentrated in the AustrianMoravian-South Polish corridor, and later Wllendorf-Kostenkian stage (25-20 ky BP), widely dispersed over central and eastern Europe. The Epigravettian, termed Kasovian (after $20 \mathrm{ky} \mathrm{BP}$ ), should be clearly separated from the earlier Gravettian stock (the radiocarbon datings used through this paper are uncalibrated). Finally, this paper gives examples of complex analyses of a typical large settlement (Pavlov I - Southeast) and of a burial site (Predmostí).
\end{abstract}

Key words: Gravettian, Ahmarian, Pavlovian,Willendorf-Kostenkian, Kasovian, settlement analysis, burial site analysis.

Résumé : Le Gravettien du cours moyen du Danube. Cet article résume les résultats récents et les points de vue actuels sur le Gravettien du cours moyen du Danube. L'origine du Gravettien semble plus complexe que ce qui était admis jusqu'ici, impliquant notamment une influence des industries à lames et lamelles à dos abattu du Proche-Orient (Ahmarien, Lagaman, Dabba) apparues avant - 40 ka BP. A la suite de son arrivée en Europe, le Gravettien danubien comporte d'abord un stade Pavlovien (30-25 ka BP, toutes dates non calibrées), limité au couloir constitué par l'Autriche, la Moravie et le sud de la Pologne. Vient ensuite un stade Willendorf-Kostienkien (25-20 ka BP) largement répandu sur l'Europe centrale et orientale. L'Epigravettien, appelé Kasovien (postérieur à 20 ka BP) doit être clairement distingué du Gravettien. Cet article présente également quelques résultats des analyses d'un grand habitat (Pavlov 1 - sudest) et d'un site funéraire (Predmosti).

Mots-clés : Gravettien, Ahmarien, Pavlovien,Willendorf-Kostienkien, Kasovien, habitat, site funéraire.

\section{INTRODUCTION}

The Gravettian, as the most complex Upper Paleolithic cultural entity in the Danubian Europe, presents a constant focal point in regional prehistoric studies and subject of regularly organized international meetings, as at Pavlov in 1995 (Roebroeks et al., eds. 2000), at Mikulov in 2002 (Svoboda \& Sedlácková, eds., 2004), and currently in Vienna in 2005. Several overview papers on the Middle Danube Gravettian were presented in the edited volumes that resulted from these conferences (Svoboda et al. 2000; Oliva 2000; Dobosi 2000; Otte \& Noiret 2004; Haesaerts et al. 2004; Jöris \& Weninger 2004; Svoboda 2004). Given this amount of previous synthetic literature, including lists with earlier references, this paper focuses on the actual results, current viewpoints, and more recent literary references.

In the present moment, excavations are in course at the Gravettian sites in Lower Austria, on the Danube (Krems Wachtberg and Hundsteig; Einwögerer 2004; Fladerer \& Salcher 2004) and Lower March (Grub/Kranawetberg, Antl, Fladerer 2004; Nigst 2004). In Moravia, excavations are running at Dolní Vestonice and Predmostí (excavation project by J. Svoboda and M. Jones in 2005-2006) and Middle Moravia Basin (Spytihnev, Jarosov and Borsice; Skrdla, ed. 2005). A new site, named Pavlov VI, has been discovered in 2007. At the same time, earlier excavated sites are being revised and prepared for new publications, as in Bohemia (Jenerálka, Revnice, Lubná; project by P. Sída), Moravia (Pavlov I; Svoboda, ed. 2005; Milovice, project by M.Oliva), Silesia (Petrkovice; project by J. Svoboda), Slovakia (Cejkov; Kaminská \& Tomásková 2004; Kasov; Novák 2004; Trencianské Bohuslavice, project by O. Zaar) and Hungary (Bodrogkeresztúr-Henye; Dobosi, ed. 2000). Specifically, sites of the Danubian Gravettian provided a relatively large series of modern human fossil remains. From this viewpoint, the most important new discoveries of 2005 and 2006 are the spectacular finds of newborn babies, ritually buried at Krems-Wachtberg (Einwögerer et al. 2006). At the same time, several research and publication projects aim to complex evaluation of the previously collected anthropological evidence from the classical sites of Dolní Vestonice - Pavlov (Trinkaus \& Svoboda, eds. 2006) and Predmostí (Velemínská et al. 2004; Svoboda 2005).

(1) Institute of Archeology, ASCR, Kralovopolska 147, CZ - 61200 Brno and departement of Anthropology, Masaryk University, Vinaska 5, Brno - svoboda@iabmo.cz 
From the viewpoint of paleoclimate and environment, the Mid-Upper Paleolithic, or later Interpleniglacial (terminal oxygen isotope stage 3 and early stage 2), was a period of global climatic instability leading towards the Last Glacial Maximum (Klíma et al. 1962). Wherever complex stratigraphies are present, as at Willendorf II with multiple Gravettian occupations, the loess/paleosol sequences suggest a dynamic climatic evolution in a "staccato" rhythm (Haesaerts et al. 1996 ; 2004 ; this volume). At Predmostí l, the old excavation records supported by the new 2006 excavation results document a superposition of two main Gravettian stages. Elsewhere, in the absence of well structured vertical sequences, chronological studies are based on the spatial analysis of the large sites (Pavlov I, Dolní Vestonice II, Petrkovice I), on radiocarbon dating, and wherever possible, on microstratigraphic analysis of the thick cultural layers (Svoboda 2003a).

\section{Origin and formation of the Gravettian}

One of the hotly debated questions in paleoanthropology, molecular genetics, and archaeology is wheather modern human penetration from Africa and the Near East to the northern latitudes was a single or multiple event. In terms of archaeology, the distributions of dates and sites in time and space for the individual entities of the Upper Paleolithic suggest a variety of answers in the individual cases. In case of the Bohunician, for example, we do not know who were the producers anatomically all we know is that they appeared at the right time at the right places. The Aurignacian was an entity created by the invading modern humans (Teschler-Nicola, ed. 2006), but the related techno/typology and symbolic behavior was most probably formed at place, after the occupation of the Danubian Europe. The Gravettian question seems to be more complex one, where both local developmental trends and outside impulses should be combined (Svoboda 2007). The Gravettian modern humans, even if inhabiting glacial Europe, conserved a more tropically adapted body form which suggests an elevated, and perphaps repeated gene flows from more temperate regions (Holliday 1997; Pearson 2000; Churchill et al. 2000).

Until now, central European researchers - including myself expected a local origin of the Gravettian, but the new typological and chronological studies make the search for a direct ancestry more and more difficult. A link to the Aurignacian is unlikely due not only to the lack of typological connection, but also to partial chronological overlapping between the two entities. Another option, a relationship to the Szeletian, is being rejected ever since the absence of foliate leafpoints was attested for the Early Gravettian (and proved, inversely, in the Late Gravettian). The Bohunician certainly accelerated the trends towards blade technology in general, but a direct link to the Gravettian cannot be traced. Therefore, somehow shadowy formulation resulted from this uncertainity, suggesting that the Gravettian appears in Danubian Europe as a "Deus ex machina" - in a complex situation composed by a variety of the preceding Early Upper Paleolithic entities.
In this paper I suggest that, in terms of the techno/typological relationships of the lithic industries, the Gravettian of Europe may well be compared to blade industries with pointed blades, bladelets, and backed elements (the Ahmarian, Lagaman and Dabban), starting about 10 ky earlier in the eastem Mediterranean (fig. 1). Early Ahmarian knapping methods aimed for production of series of pointed blades and microblades from unipolar narrow-fronted cores may be compared to a variety of blade and microblade knapping techniques as recorded at Pavlov by Skrdla (1997), for example, even if the importance of the bipolar technique increased markedly in the Gravettian. Some of the el-Wad points in the Near East are at least partly backed, as are the La Gravette points in Europe (an observation made already by Garrod), whereas the finer el-Wad points recall the Font Yves or Krems points of central Europe. The rest, i.e. the variable representations of endscrapers and burins on blades and their specific morphology is analogous in the Ahmarian, Lagaman, Dabba, and the Gravettian.

Recent research by the French and Bulgarian teams in the Balkans has possibly overbridged the important gap of the 10 ky between the appearance of Ahmarian in the Near East and the dispersal of Gravettian in the Danubian Europe by inserting in an early Gravettian (Kozamikian) industry from Kozarnika cave (layer VII). This industry, including microblades, backed blades and points recalling the el-Wad type, is dated as early as $39 \mathrm{ky}-36 \mathrm{ky} \mathrm{BP}$ (Tsanova 2006). Another comparable industry appeared in the western Caucasus (Golovanova et al. 2006). On the other hand, more care would be advisable in arguing about the date of 35,5 ky for the "Proto-Aurignacien" of KremsHundsteig in Austria, an industry which, in fact, may result from mixing the Aurignacian and Gravettian layers during the excavations more than 100 years ago. Intensive research is carried out at Krems actually, both at the sites of Hundsteig and Wachtberg, and new data may be expected in the near future.

However, even if we propose - on the basis of lithics - that the Gravettian may be more or less directly related to the earlier backed-blade industries of eastern Mediterranean, it should also be stressed that formation of the complex Gravettian culture including the large open-air settlements, with industries of organic materials, art, symbolism, and ritual burials, was a local Danubian adaptation.

\section{Early Gravettian - The Pavlovian}

As the most important component of the Early Gravettian in Danubian Europe, the Pavlovian (30 - 25 ky) occupies a central location within the Lower Austrian - Moravian South Polish geomorphological corridor (fig. 2a). Both the Pavlovian settlement archaeology and the resource analysis suggest a discontinuity compared to the previous Early Upper Paleolithic settlement strategies: the typical formation of the large open-air settlements in an axial manner, in lower altitudes and along the rivers; the long-distance transport of lithic raw materials; the intensive exploitation of mammoths supplemented by a variety of small animals; and, finally, aspects of ritual and style. 


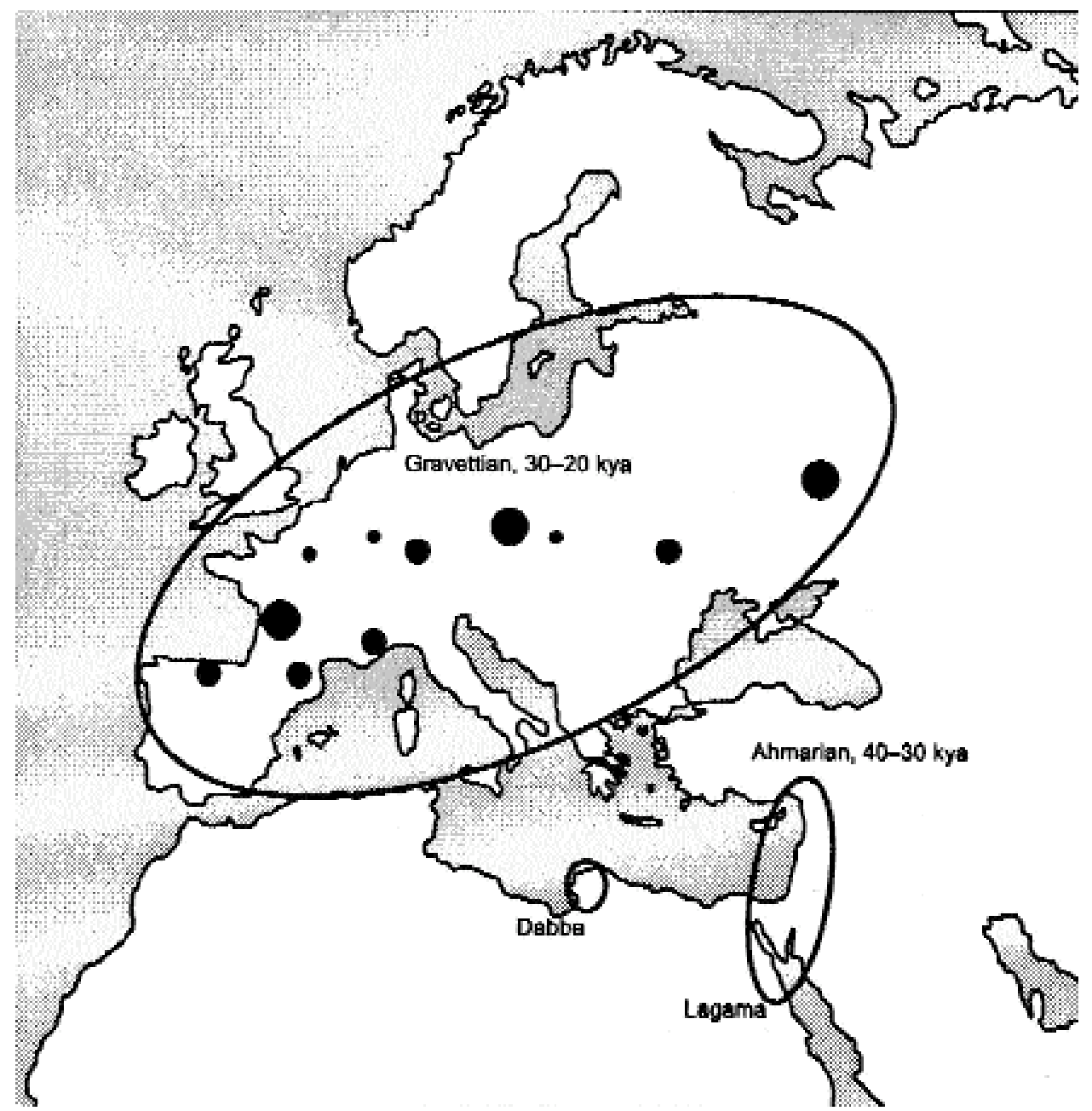

Figure 1 - Schematic map of the Mediterranean backed industries (Ahmarian, Lagaman, Dabba) of the Near East and the Gravettian of Europe.

Figure 1 - Carte schématique des industries méditerranéennes à dos abattu (Ahmarien, Lagaman, Dabba) du Proche-Orient et du Gravettien européen.

In addition, the lithic industries are accompanied by a rich and varied industries of organic materials. In case of the bone/ivory/antler industry, the morphological variability suggests a multiplicity of functions (Klíma 1997; Zelinkova 2007), but the interpretation, including the archeological nomenclature of certain implements, is still poorly understood. Recently, Brühl (2005) suggested that some of the "shovel-shaped" tools may in fact be blunt bone projectiles aimed for hunting fur animals without damaging the skins, whereas Steguweit (2005) interpreted some of the ivory "cylinders" ar soft hammers. The discovery of textile imprints on surface of certain ceramic fragments may, logically, imply a variety of textile-producing functions for the bone industry (Soffer \& Adovasio 2004). However, we still lack a systematic description and nomenclature of the bone industry in general.

The art production at this stage of the Gravettian is remarkably complex, and includes carvings and engravings, soft stone carvings, and especially the ceramic plastic produc- tion. This phenomenon, typical of the Pavlovian, is worth special attention that lies beyond the scope of this summary paper.

Finally, majority of the human skeletal remains are equally dated to this period (Predmostí, Dolní Vestonice - Pavlov, Krems). Some of the ritual burials are covered by ochre, and some are covered by mammoth shoulderblades. It should be underlined, however, that they are poorly equipped by additive artifacts (if any, so just a few pierced decorative objects; Trinkaus et Svoboda, eds., 2006; Einwögerer et al. 2006).

The earliest Pavlovian occupation is best documented at Willendorf II, layer 5 (around and after 30 ky BP), Krems, and Dolní Vestonice II (a complex occupation horizons dated to $27 \mathrm{ky}$ ). The industry is dominated by burins, backed implements, and endscrapers, where burins are about the twice as numerous as endscrapers. The number of microliths, and especially geometric microliths, is usually low. A variety of pointed blades (including the 

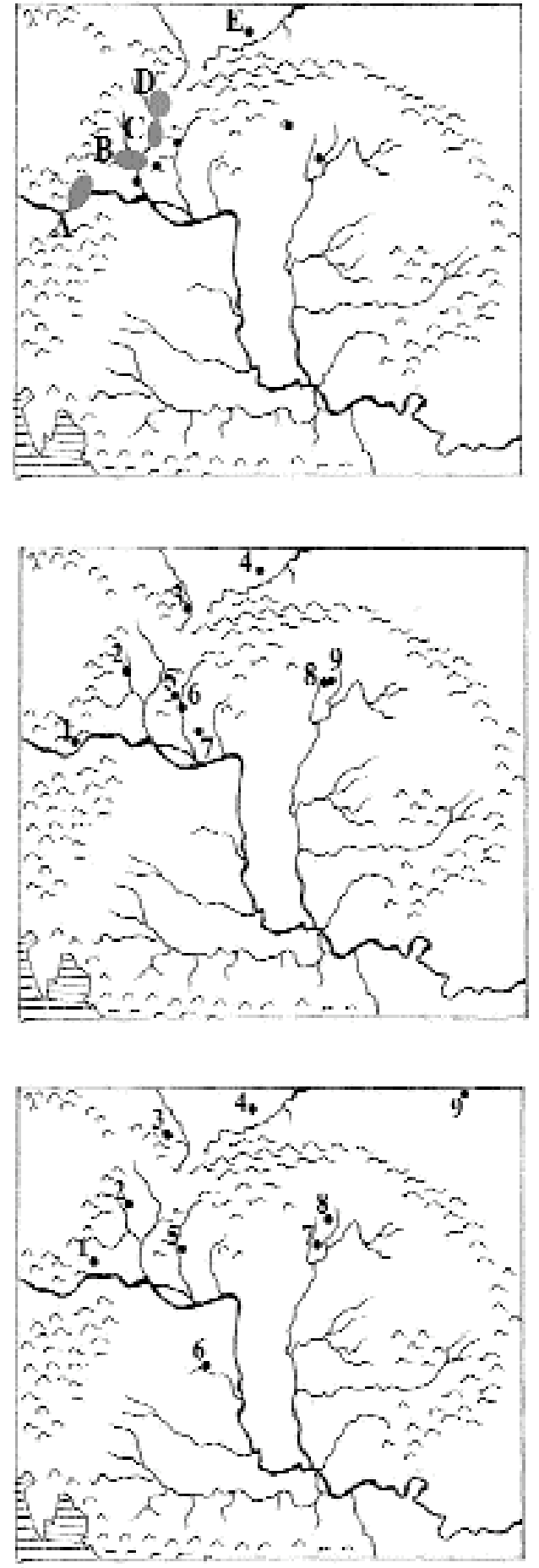

Figure 2a - Map of the Early Gravettian (Pavlovian) sites in the Middle Danube region.

A: sites of the Wachau Gate,

B: Dolní Vestonice - Pavlov,

C: Middle Morava Basin,

D: Predmostí,

E: Cracovie.

Figure 2a - Carte des sites du Gravettien ancien (Pavlovien) du Danube moyen.

Figure $2 b$ - Map of the Upper Gravettian (Willendorf-Kostenki) sites in the Middle Danube region.

1: Willendorf (layer 9),

2: Brno II,

3: Petrkovice,

4: Cracovie,

5: Trencianské Bohuslavice,

6: Moravany,

7: Nitra-Cermán,

8: Cejkov,

9: Kasov (lower layer).

Figure $2 b$ - Carte des sites du Gravettien supérieur (WillendorfKostienkien) du Danube moyen.

Figure 2c - Map of the Epigravettien (Kasovian) sites in the Middle Danube region.

1: Grubgraben,

2: Stránská skála $N$,

3: Opava,

4: Cracovie,

5: Banka,

6: Szágvár,

7: Arka,

8: Kasov (upper layer),

9: Lipa.

Figure 2c - Carte des sites Epigravettiens (Kasovien) du Danube moyen
Jerzmanowice-type points) and pointed microblades (including the Krems or Font Yves points) occur as well. A remarkable cluster of Pavlovian radiocarbon dates is recorded during the following two millenia, between 27 25 ky (Jöris \& Weninger 2004). These dates were received from Willendorf II (layers 6-8), Aggsbach, Krems, Grub/Kranawetberg, Dolní Vestonice - Pavlov, Milovice (settlement), Borsice, Jarosov (settlement), Spytihnev, and Predmostí (the main occupation layer). An increase of microliths, including the geometric microliths (lunates, tri- angles, trapezes), is typical at this stage, especially within the Dolní Vestonice - Pavlov area (fig. 3). A variety of pointed blades and microblades continue to occur, but the typical leaf-points are absent at this stage. A few of the ${ }^{14} \mathrm{C}$ datings from sites like Dolní Vestonice, Milovice and Jarosov are later than $25 \mathrm{ky}$; so, for example, the mammoth bone deposits at Milovice and Jarosov are dated later than the related settlements. If these dates are correct, they would suggest a prolongation of occupation at these sites after the Pavlovian. 


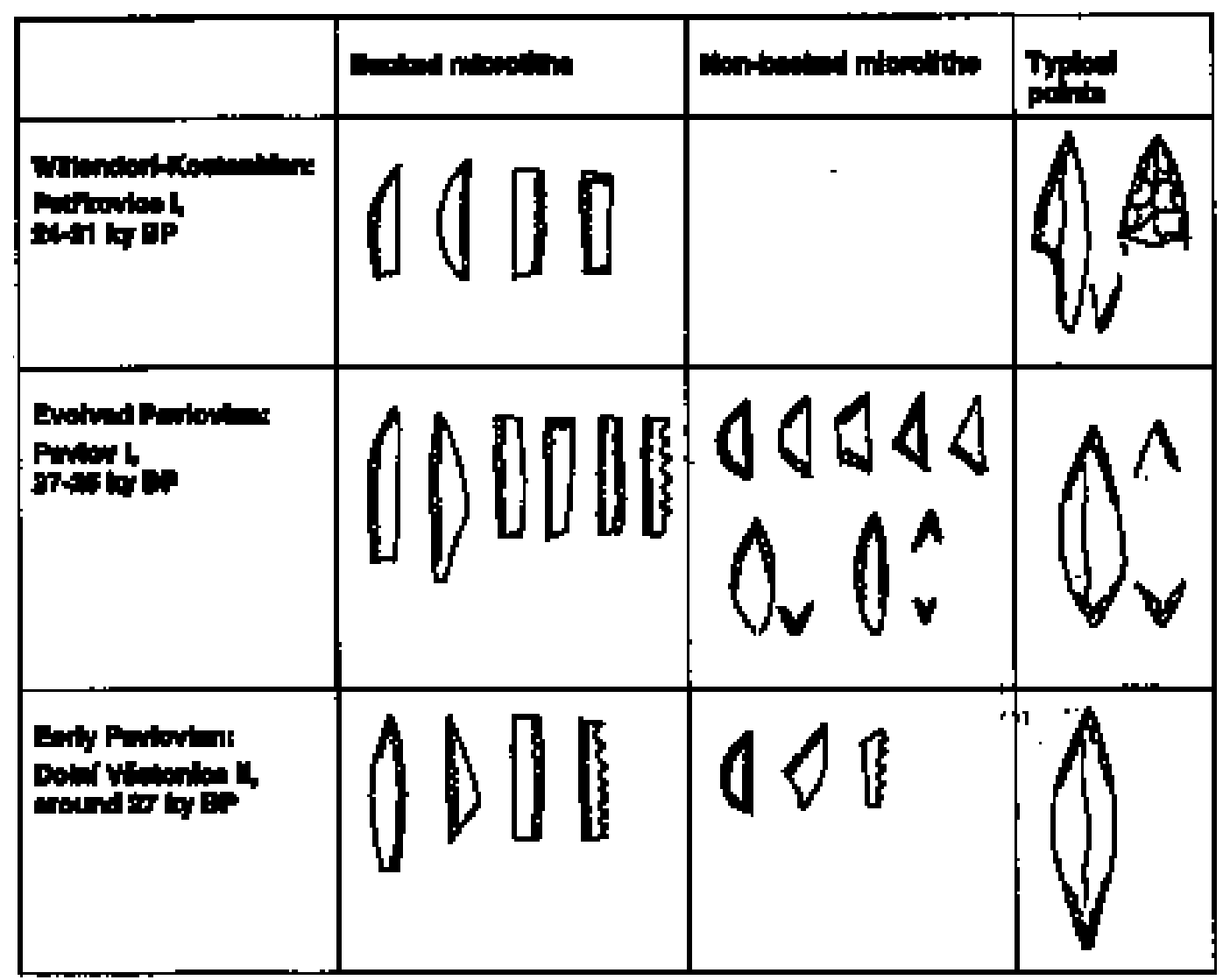

Figure 3 - Comparison of the Pavlovian and Willendorf-Kostenkian stages in Moravia and Silesia: aspects of typology, with emphasis on microliths and points.

Figure 3 - Comparaison typologique et plus particulièrement des microlithes et pointes entre le Pavlovien et le WillendorfKostienkien de Moravie et de Silésie.

The most typical example of another type of Early Gravettian, non-Pavlovian site, is Bodrogkeresztúr-Henye in eastern Hungary (Dobosi, ed. 2000). The site provided two dates, $28.7 \pm 3 \mathrm{ky}$ and $26.3 \pm 0.4 \mathrm{ky}$ that place it chronologically to the Early Gravettian. Contrary to the Pavlovian sites, however, the fauna is dominated by horse and elk, and the lithic industry, dominated by burins, retouched blades, endscrapers and sidescrapers, lacks the typical microliths.

In addition, there are differences of rather functional nature. Nemsová, a workshop site with an Early Gravettian date in westem Slovakia, is located near an important raw material source: the radiolarite. Two smaller cave sites, Slaninova Cave and Dzeravá skala Cave, yielded early Gravettian dates in association with fragments of the typical ivory points with circular section. This may be an evidence for periodical visits of Gravettian hunters in the karstic regions.

\section{Upper Gravettian - the WIlendorf-Kostenkian}

After 25 ky, approximatively, the Middle Danubian region becomes covered by a network of Upper Gravettian sites (fig. 2b). Compared to the Pavlovian, however, we observe larger and less regular distances among the sites, with more emphasis on the "gates" (Wachau Gate, Moravian
Gate), but also dispersal into new regions, especially in the Carpathian Basin. The art assemblages are less complex: instead of the large and varied assemblages of the Pavlovian art, we mostly have remarkable female images only, such as the oolithic figurine of Willendorf II, the hematite figurine of Petrkovice and the ivory figurine of Moravany (therefore, we sometimes speak of "horizon of lonely Venuses"). There is only one burial, Brno II, with a date of 23,7 ky (Pettitt \& Trinkaus 2000; Oliva 2001). It differs from the Pavlovian burials by the richess of associated objects such as the male figurine of ivory, marlstone discs, and smaller items of body decoration.

The most typical site is the uppermost layer 9 of the classical stratigraphic sequence at Willendorf II in Austria, providing a typical industry with shouldered points, the "fossil directeur" of the period with a series of ${ }^{14} \mathrm{C}$ dates ranging from 25 to 23 ky (Haesaerts et al. 1996; NeugebauerMaresch 1999). Moravia, compared to the previous period, received scarce evidence of occupation at this time-period, as at Predmostí, upper layer, dated 24,3 ky. A typical site of this period is Petrkovice in Silesia, with five dates between 21-23 ky, and a network of Upper Gravettian sites of a similar age in Slovakia, as at Trencianské Bohuslavice, Moravany, Nitra-Cermán, Cejkov and Kasov (lower layer). 
In addition to the typical shouldered points, certain sites of this time-period also provided leaf-points (Petrkovice, Trencianské Bohuslavice, and Predmostí - the upper layer). Genetic relationships to the Szeletian, formerly anticipated by certain authors, are unlikely given the long timespan separating the two periods. Rather, we expect an independent wave of leaf-production at $20 \mathrm{ky} \mathrm{BP,} \mathrm{which,}$ by the time of the Last Glacial Maximum, seems to be an element of evercontinental significance (cf. the Solutrean of western Europe).

\section{Epigravettian - the Kasovian}

Industries from Middle Danube region dated after the Last Glacial Maximum (20-15 ka BP) were hitherto presented as a "mosaic" of derived Gravettian and Aurignacian features (Grubgraben, Stránská skála, Szágvár, Arka, Kasov - upper layer, Lipa; Svoboda et al. 1996; Valoch 1996, etc.). Actually, following a preliminary revision of the sites and redating of some of them (Moravany-Zakovská as the Upper Gravettian, Verpoorte 2002; Hranice as the Magdalenian), the techno/typological structure becomes more homogenous and we propose to unite the remaining industries into a distinct techno/typological unit (Svoboda \& Novák 2004).

These sites form a network of scarcely distributed sites over the Middle Danubian region (fig. 2c). In terms of raw material exploitation and economy, there is more emphasis on local sources, and the sites located directly in vicinity of the outcrops display the character of primary workshops (Arka, Lipa). Contrary to the Gravettian based predominantly on lithic imports and producing long blades from the classical crested and prismatic cores, the Epigravettian blanks (flakes, shorter blades, microblades) are produced from short and cubical cores as well as from elongated blade cores. Typically, some of the microblades were made by pressure technique from wedge-shaped cores strongly recalling the North Asian parallels. Typologically, the groups of short endscrapers and burins predominate, but their quantitative relationship may be flexible at the individual sites. Both types are usually made on short blanks. Some of them are thick and some are polyhedric, thus recalling «Aurignacian» forms, but the quantity of these types is low. The backed implements, previously used as the key argument for continuity of the Gravettian tradition, are also present (cf. Arka, Lipa) but are in fact less frequent than was expected. In addition, the bone-and-antler industry, whenever preserved, shows parallels to the Magdalenian ("bâtons de commandement" at Grubgraben and Ságvár, needles at Grubgraben) rather than to the rich bone industry of the preceding Gravettian. Symbolic art is absent.

These techno/typological changes copy with radical changes in settlement strategy (preference for slopes and protected valleys), hunting techniques and strategies (termination of the mammoth exploitation and orientation on horse and reindeer herd hunting, West 1996). Thus, we argue that in the Middle Danube region, the Gravettian/Epigravettian continuity has been interrupted, most probably as a result of the Last Glacial Maximum.
As the terms "Epigravettian", "Epiaurignacian", or even "Protomagdalenian" are missleading by the nature of their meaning, we may either look for parallels in the contemporary development elsewhere (e.g., the Badegoulian of Western Europe, Terberger \& Street 2002) or coin a new name valid for eastemCentral Europe. The earlier suggested names such as the Lipa culture or the Ságvárian were used in a more local sense and never refered to the whole geographic entity as is observed over the whole Middle Danube region. The site of Grubgraben, recently proposed by Terberger (2003) has the advantage of a solid dating framework associated to a wealth of archaeological evidence, but the typological structure seems more versatile compared to the other sites; therefore, it is difficult to characterize the site typologically before the publication of the complete material.

A candidate could be the site of Kasov - upper layer (Bánesz et al. 1992). Even if we only have one ${ }^{14} \mathrm{C}$ date (18,6 ky BP), this site documents a simple but clear stratigraphy, and a rich but typologically standard and characteristic archaeological content. Hence, we proposed the term "Kasovian" for further discussion (Svoboda \& Novák 2004). The term "Epigravettian", sensu stricto, should be reserved for Mediterranean Europe, where the Gravettian typological tradition is clearly conserved and further developed (backed implements and microliths). In contrast, the typological characteristic of the Kasovian lies closer to the Badegoulian of the west of Europe, or to the other entities further to the east of the North Eurasia.

\section{Gravettian Landscape: the Moravian Corridor}

Danube, given the west-east orientation accross the Central and Southeast Central Europe, unifies the mosaic of plains separated by highlands and mountaneous chains. This river emerges from the west in the narrow Wachau Gate in Austria, and, after accepting two affluents from the north, Morava and Váh (both linked with the Gravettian sites), it turns suddenly towards the south to cross the Hungarian Plain. Two other affluents are important on this joumey, Tisza, connecting Gravettian sites of eastern Hungary and Slovakia in the northeast, and Sava in the southwest.

The regional literature rightfully emphasizes the role of the Moravian Gate as one of the most important European passages, both for animals and their hunters. The bottleneck of the gate itself, and the adjacent Moravian corridor composed of narrow plains between the Bohemian Massif and the western Carpathians, provides the easiest passage from the Danube valley towards the plains of Northem and Eastern Europe. Spatial patterning of the Upper Paleolithic sites shows that no other entity adapted its sitelocation strategy to the Moravian geomorphology as precisely as the Gravettian. The largest and most complex sites are located along this corridor axially, in almost regular distances, starting with the Willendorf, Aggsbach and Krems cluster at the end of the Wachau Gate in the southwest, towards the Dolní Vestonice-Pavlov cluster and further through the Middle Morava Basin towards the Predmostí sites at the southern end of the Moravian Gate and Petrkovice at the northemend.

Theoretically, there are several levels of spatial analysis of the Danubian Gravettian (Svoboda 2003b): 
- the Gravettian landscape is related to the riverine network of Moravia, where sites and site-clusters are localized on the valley slopes and elevations, in relatively lower altitudes (200 - 300 m a.s.I.), with almost regular distances between one another. The Dolní Vestonice-Pavlov area is a typical example (fig. 4-5). In constrast, the "Aurignacian landscape" favours higher locations, and was less dependent on the Moravian rivers;

- the individual sites demonstrate a distinguished hierarchy with regards to their size and complexity. Another factor is the function of sites, their universality or specialization, so that the nature of the difference is both quantitative and qualitative. Finally, occupation of a site has a rhythm and dynamics of its own, in terms of seasonality, microchronology (relationships between units and features within the sites, microstratigraphies) and of the overall Gravettian chronology. Therefore, the sites represent units composed by elements and factors of incomparable nature, requiring various analytical approaches;

- the settlement units. Large sites are sectioned into individual units (central hearths with related features, objects, and patterns of artifact distribution); the spatial/temporal relationships among them are the object of a site analysis. Dwelling structures are, in fact, ideal architectural reconstructions of the settlement units.

\section{Large Gravettian settlements: the Pavlov case}

Formation of the large hunter's settlements is a characteristic phenomenon of the Pavlovian (Kozlowski 1986; Valoch 1996; Svoboda et al. 1996, 2000; NeugebauerMaresch 1999; Verpoorte 2001, etc.). The first characteristic of these "mega-sites" is simply their size (minimal diameter of $100 \mathrm{~m}$ ). In addition, the evidence of a high artifact density, thickness of cultural layers and charcoal deposits, the complexity of activities, including rituals and symbolism has been recorded. While interpreting the records, two extreme models are usually applied: the first model proposes a large, relatively sedentary, "camp"; the second model suggests an accumulation of successive short-term occupations. Or, in another words, two site-formation factors are involved: the intensity of occupation on one hand, and its duration on the other.

The large and complex sites, with extended and intensive occupations and complexity of art and other symbolic production, are Dolní Vestonice I and Pavlov I, as well as Predmostí I. Dolní Vestonice II is large in size, but the occupation was less intensive and more structured in time and space than the above sites. Other important sites are at Krems (Wachtberg and Hundsteig), Grub, and others. Willendorf II, on the other hand, is important stratigraphically, as a repeatedly but only shortly visited landmark (with the exception of a more extended layer 9). Preliminary

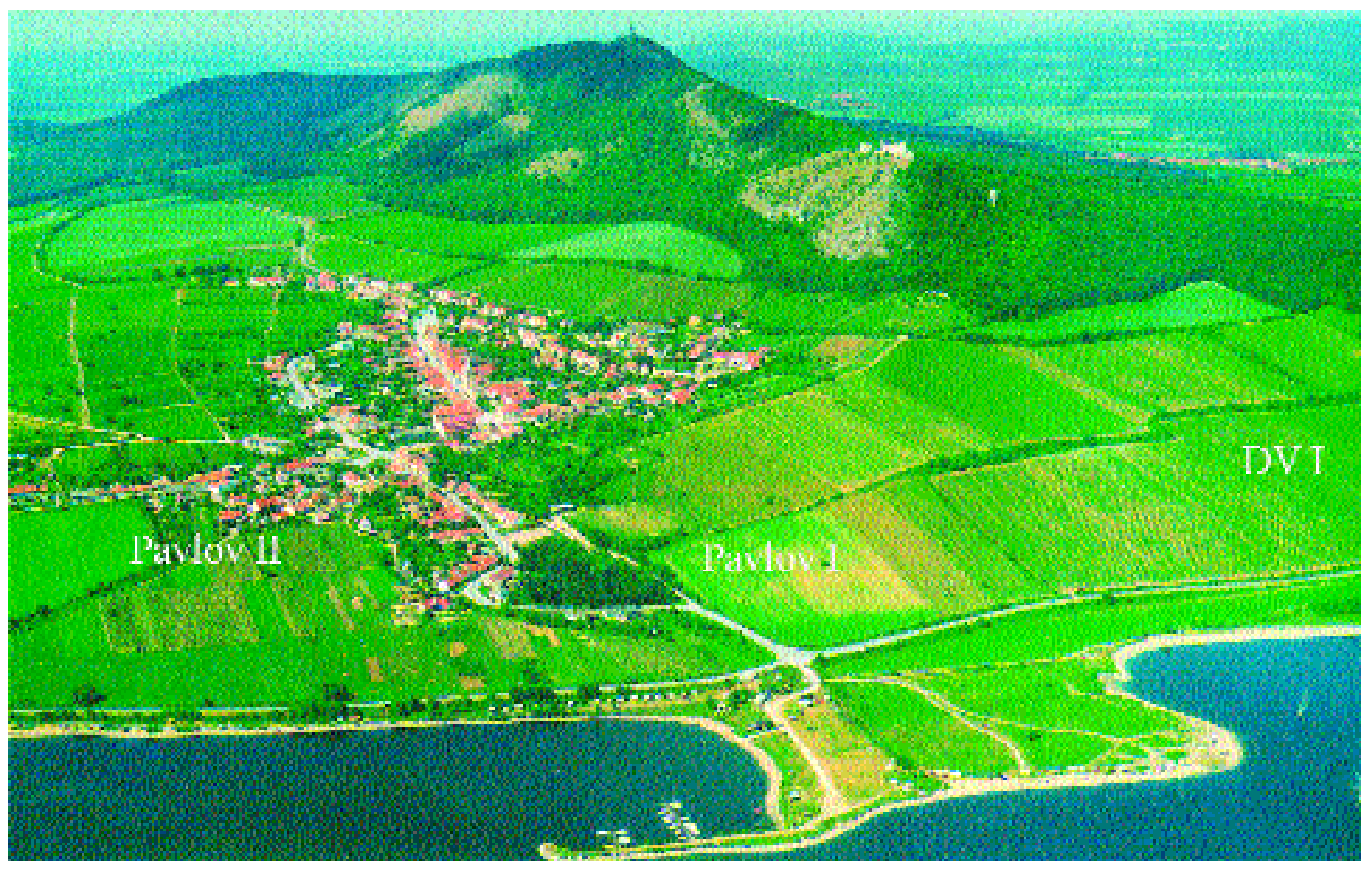

Figure 4 - Aerial view of the Dolní Vestonice - Pavlov sites.

Figure 4 - Vue aérienne des sites de Dolni Vestonice et de Pavlov. 


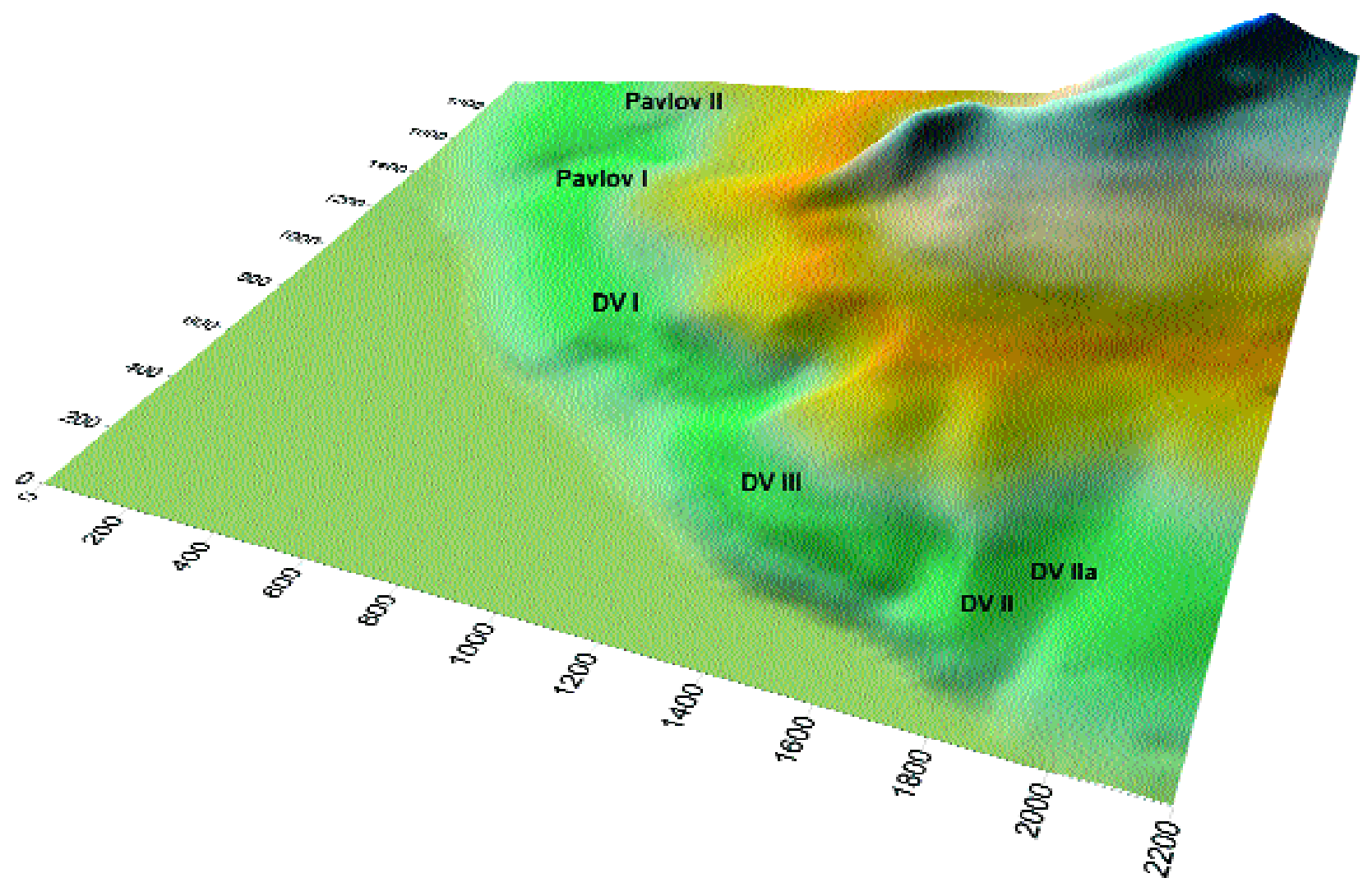

Figure 5 - Surfer reconstruction of the site location within the Dolní Vestonice - Pavlov area.

Figure 5 - Reconstitution 3D des sites des zones de Dolni Vestonice et Pavlov.

results obtained on seasonality by Nyvltova Fisakova (2007), based on animal dental microstructures, suggest that the large sites were settled all the year round, whereas some of the smaller sites in the region functioned seasonally (spring-autumn).

The advantage of Pavlov I is that it was excavated by one person, Bohuslav Klíma, on a large scale, and using a single research strategy (Klíma 2005). In the early 90s, we initiated a long-term, multidisciplinary, international process of description and evaluation of the site and its inventories. We started with a pilot area in the Southeastern part (Svoboda, ed. 1994), and continued in the Northwestem part (Svoboda, ed. 1997), so that the results gave us the opportunity to compare the situations in the two opposite areas. With the first comparative results at hand, the consecutive step was to approach the densely settled parts excavated in 1954 and 1956, with the richest and the most complex evidence, and thus to complete the picture of Pavlov - Southeast (Svoboda, ed. 2005).

The data-set based on $1 \mathrm{~m}$ or $2 \mathrm{~m}$ square grid recording systems, and on incomplete provenience data about the microstratigraphies, certainly represents a rough scale compared to modern excavation standards. Therefore, more detailed insights into artifact clustering were not possible, but we are able to operate on another scale, within a considerably larger area, and with larger features such as hearths, depressions, and artifact clusters.
While identifying the 13 features, or "huts", B. Klíma (2005) combined several viewpoints of a different character and value: hearths, pits, large bones along the edges, the spatial extent of the cultural layer, and artifact concentrations. Our approach was to analyze each of these components separately. The depressions were reconstncted newly, using a Surfer approximation of the data derived directly from the stratigraphic sections (fig. 6; Svoboda, ed. 2005). The distribution patterns were analysed subsequently, separately for each type of artifacts (Novák 2005), and than plotted over the surface reconstnction. The aim was to distinguish more clearly the levels of empirical observation ("settlement units") from interpretation ("dwellings").

One of the results of our analysis address the difference between the central and the peripheral parts of the settlement from the viewpoints of microstratigraphies, features, and of the spatial distribution of the artifacts. Generally, the palimpsest area ranges over the central and the western parts of the area, with irregular, multiplied features $7-11$, whereas the settlement record seems plainer, and easily readable along the peripheries (features $3,5,6$ ). Other contributors, while discussing the individual types of artifacts in detail, analysed this problem from their specific viewpoints. For Verpoorte (2005), the central part of the site is just a palimpsest of various occupation episodes. Bartosíková (2005) located, at the periphery of the site, the "production areas" and the 


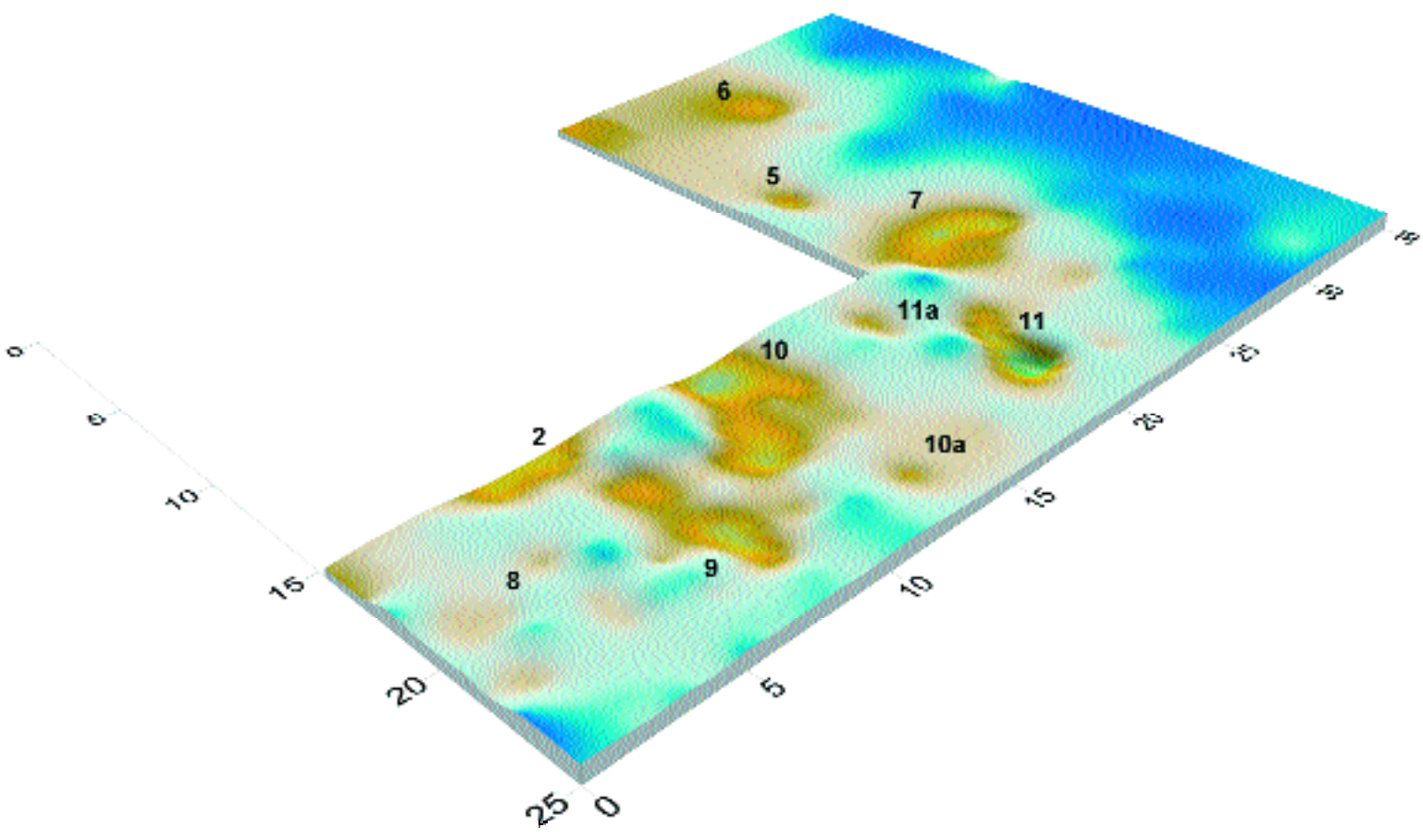

Figure 6 - Approximative Surfer reconstruction of the numbered depression features (huts?) at Pavlov I - Southeast (19541956 excavation seasons), based on data from the stratigraphic sections. The feature numbers (2, 5-11) follow and complete the numeration system by the excavator.

Figure 6 - Reconstitution approximative des structures en creux (huttes ?) enregistrées à Pavlov sud-est (fouilles 1954-1956) à partir des coupes stratigraphiques. La numérotation des structures $(2,5$ - 11) suit et complète le système de numérotation du fouilleur.

"working places" (the later using already finished products); however, it is suggested that the two types of activities spatially overlapped. Sajnerová (2005) recorded a higher percentage of used pieces in the center and, in addition, traces of working hard materials in these areas. Musil (2005) defined several activity areas on the basis of the faunal remains, together with their relationships to the individual settlement units, and, on a larger scale, to the settlement areas.

Another question touches upon the settlement dynamics and seasonality. Musil, based on the faunal analysis, and Verpoorte, on the basis of the lithics, argue for a permanent or semi-permanent occupation of this site, with emphasis on winter seasons. Even if the settlement would be rather permanent and related to a limited hunting territory, the spring migrations along Moravian drainage system are expected. This scenario would accord with the records of a large volume of lithic material imported from the northeast and east.

While discussing the faunal remains, several points should be considered. Firstly, the records may not be complete because of the limitation of the excavated area, or because of erosions in the adjacent valley of an active brook (this could explain why we at Pavlov I lack mammoth bone deposits which are typical features of Dolní Vestonice I, II, Predmostí I, and Milovice I sites). Secondly, the faunal structure we have received from Pavlov I resulted from a deliberate human selection. However, an animal not only served as a source of meat and fat for nutrition, but also of furs for clothing and building, and of bones for tools, buildings, and fuel. Certain camivores may have appeared on the faunal list simply as animals being killed when attacking the site and the food stored there.

After Musil (2005), the dominant animal species were reindeer, hares, wolves, foxes, mammoths, and horses, respectively. As Wojtal et al. (2005) remark, reindeer and hare bones also bear the majority of the visible cut marks, which is in an agreement with their importance on the faunal records. However, as emphasized by Nyvltová Fisáková (2005), Brühl (2005), and García Diez (2005a), mammoth remains, especially the precious ivory, formed more than a half of the materials selected for the production of tools and decorations (followed by reindeer and fox remains). Faunal analysis is closely related to study of possible hunting weapons. The composite projectiles made of backed and/or geometric microliths were never recovered "in situ", nor confirmed by the use-wear analysis, but their existence is usually admitted. Brühl (2005), based on analogies with ethnology, turned his attention to the blunt "foliates" made of organic material, which could have been intended for killing smaller animals in order not to damage the furs. In addition, using nets was probably another hunting technique, especially with the smaller fur animals, as suggested by the knot imprints in ceramics (Adovasio et al. 2005; Kovacic et al. 2005). 
Since the publication by Mason et al. (1994) of ground plant tissue in a hearth at Dolní Vestonice II, there is no further evidence confirming plant consumption, a supplementary activity that should be presumed at these sites. Thus, based on the number of grindstones documented at Pavlov I, this problem is raised again (Svoboda, ed. 2005). However, the available evidence shows that the majority of the grindstones were evidently used for colorants, while other possible usage remains unacknowledged. New excavation project at the same site, now oriented towards the paleobotanical analysis and bases on extensive floating of the sediments, has been initiated in 2005 in collaboration with the University of Cambridge (M. Jones).

Pavlov I witnessed a broad variety of techniques and objects of self-adornment. Namely, the collection and simple usage (or perforation) of naturfacts such as camivore teeth and the Tertiary molluscs (Hladilová 2005), supplemented by ivory beads and other more sophisticated, and perhaps more "symbolic", items of decoration (García Diez 2005a). In additon to items of decoration, there are also symbols of their own such as the ivory carvings depicting a lion and a mammoth. Soffer and Vandiver (2005) wonder about the twodimensional aspect of these images. I believe that this may be due to the fact that both were, in fact, attached to clothings as were the other items of decoration. The morphology of these "contours découpées", and especially the notches, would support this interpretation.

The most typical phenomenon of the Pavlovian art is the production of clay plastics - the earliest ceramics. Even though this production is also recorded elsewhere in Moravia (Predmostí and sites of the Morava river valley), lower Austria (Krems), Silesia (Petrkovice) and Slovakia (Moravany, Cejkov, and Kasov), the South Moravian sites of Pavlov I and Dolní Vestonice I represent the true centers of these activities. Similarly to the decorative objects of organic materials, the ceramics was also found clustered in three concentrations in the western part of PavlovSoutheast (features 9, 10,11), and inside of a one concentration in Pavlov-Northwest (feature 13). Logically, these concentrations were likely to be protected by a constru ction - early architecture. And, presumably, production and destnction of symbols in clay around certain hearths may, since the first discovery of such a place be interpreted as a ritual activity (Absolon 1938; Soffer et al. 1993).

Additional evidence is conserved as imprints on surface of the ceramic pieces. Microscopic examinations confirmed the existence of regular structures that are interpreted as simple textile imprints (Adovasio et al. 2005; Kovacic et al. 2005) and animal hair. Dematoglypic studies suggest that young people and children were present - and active around the ceramic production processes (Králík \& Novotny 2005). This coincides well with some of the Westem European data from painted caves, where the presence of children has also been documented. I do not wish to suggest that children were the producers of this art, neither of the "big" parietal art of the West nor of the miniatures of Moravia, but it should be taken into an account that the symbolic art production was a complex process assisted by the whole community. And - as today - children were probably anxious to touch everything directly.

If placed in context with the other symbolic activities performed at Pavlov I and Dolní Vestonice I-II, such as traces of colorants, carvings in ivory and stone, and human burials, the ceramic production suggests that these sites were the centers of activities related to rituals, information storage and transmission by the means of symbols, decoration of bodies, and their ritual deposition in graves. The traces of symbolism, concentrated especially at Dolní Vestonice I and Pavlov I, place these sites on the top of the site-hierarchy not only quantitatively - as a result of the size and volume of the excavated material, but also qualitatively - as the places of special activities. In the light of the above, the two sites are considered not only as palimpsests of accumulated subsequent occupations, but as centers of human aggregation, information exchange, and social rituals.

Of equal interest are the isolated settlement units composed just of a central hearth and encircled by pits, large bones, and artifact scatters. Most recently, a unique example of this "elementary" type of situation was discovered in 2007 about $1 \mathrm{~km}$ from Pavlov I, at the site VI (fig. 7).

\begin{tabular}{|c|c|c|c|c|c|}
\hline Site & Individual & Position & Orientation & Ochre & Items of decoration \\
\hline DV I & DV 3 & strongly flexed & NW & $\begin{array}{l}\text { head, upper part } \\
\text { of the body }\end{array}$ & 10 fox canines \\
\hline DV II & DV 13 & supine, torded & SSE & head & $\begin{array}{l}20 \text { pierced camivore teeth, } \\
\text { ivory pendants }\end{array}$ \\
\hline DV II & DV 14 & on belly & $S$ & head & $\begin{array}{l}3 \text { wolf canines, } \\
\text { ivory pendants }\end{array}$ \\
\hline DV II & DV 15 & supine & $S$ & head, pelvis & 4 pierced fox canines \\
\hline DV II & DV 16 & flexed & $E$ & head, pelvis & 4 pierced fox canines \\
\hline Pavlov I & Pavlov 1 & $\begin{array}{l}\text { flexed? } \\
\text { (disturbed) }\end{array}$ & SE & - & - \\
\hline
\end{tabular}

Table 1 - The Dolní Vestonice (DV) and Pavlov ritual burials and their archeological contexts (solitary finds are not recorded).

Tableau 1 - Les sites funéraires de Dolní Vestonice (DV) et Pavlov et leurs contextes archéologiques (les découvertes isolées ne sont pas mentionnées). 


\section{Human burials: the Predmostí case}

Burials are an integral component of the large Gravettian settlements. Human fossils appear as well-preserved ritual burials, sometimes covered by mammoth shoulderblades or other means of protection, or as disturbed situations and scattered fragments. Only a few pierced beads and teeths are associated, but parts of the bodies are usually covered by ochre. First zooarchaeological analysis of the faunal remains in the vicinity of Dolni Vestonice 16 suggest that complete animal bodies were laid next to buried man, perhaps intentionally (Nyvltova Fisakova, pers. com.). In the chronological framework, the majority of human burials from Dolní Vestonice I, II and Pavlov I, plus Predmostí I, fall into the Evolved Pavlovian stage (27 - 25 ky BP; Vlcek 1991; Klíma 1995; Trinkaus \& Svoboda, eds. 2006). An earlier Pavlovian horizon, identified at Dolní Vestonice II and dated to around 27,000 years BP, is related only to the isolated human fragments Dolní Vestonice 33, 36, 39, 47 and 49. This, at least, is the chronological picture given by standard laboratories such as Groningen.

One later burial, corresponding with the WillendorfKostenkian stage of the Gravettian, is Brno 2 (23,7 ky BP; Pettitt \& Trinkaus 2000). It is unique in two aspects; its location is outside of the typical Pavlovian regions and settlements, and it is unusually rich in grave goods. Another later date obtained directly from the Dolní Vestonice 35 femur from the site of Dolní Vestonice I (22,8 ky B.P.) may possibly be contaminated, since the majority of the other dates from the Dolní Vestonice I settlement correspond with the Evolved Pavlovian stage (Trinkaus et al. 2000).

In Austria, the 2005 and 2006 discoveries of newborn childern's burials at Krems-Wachtberg fall chronologically to the Evolved Pavlovian stage as well. The first two bodies were lain together in crouched position in a shallow pit, richly covered by ochre, and protected by a mammoth shoulderblade. The associated ivory beads are of the same type as at Dolní Vestonice. Additional infant burial was located about one meter north (Einwögerer et al. 2006). The only other human remains from the same region and time period are the isolated pieces from Willendorf I and II, which date to the Willendorf-Kostenkian (Teschler-Nicola \& Trinkaus 2001), and two human teeth recently discovered in Grub/Kranawetberg (Antl \& Fladerer 2004). Some other human fossil finds from the Middle Danube region were deleted from the list on basis of direct ${ }^{14} \mathrm{C}$ dating (Svoboda et al. 2002).

In this context, Predmostíl still represents the largest accumulation of Gravettian human remains at one place (e.g., Klíma 1991; Valoch 1996; Oliva 2001). These materials were recovered by J. Wankel in 1884, K.J. Maska in 1894, M. Kríz in 1895 and K. Absolon in 1928 (and probably 1930). The majority of the Gravettian anthropological materials from Predmostí were destroyed in 1945; today, the Moravian Museum at Brno only houses cranial fragments including teeth of unclear origin and parts of the postcranial remains. However during the last few years, the first mandible found at this site by Wankel was redis-

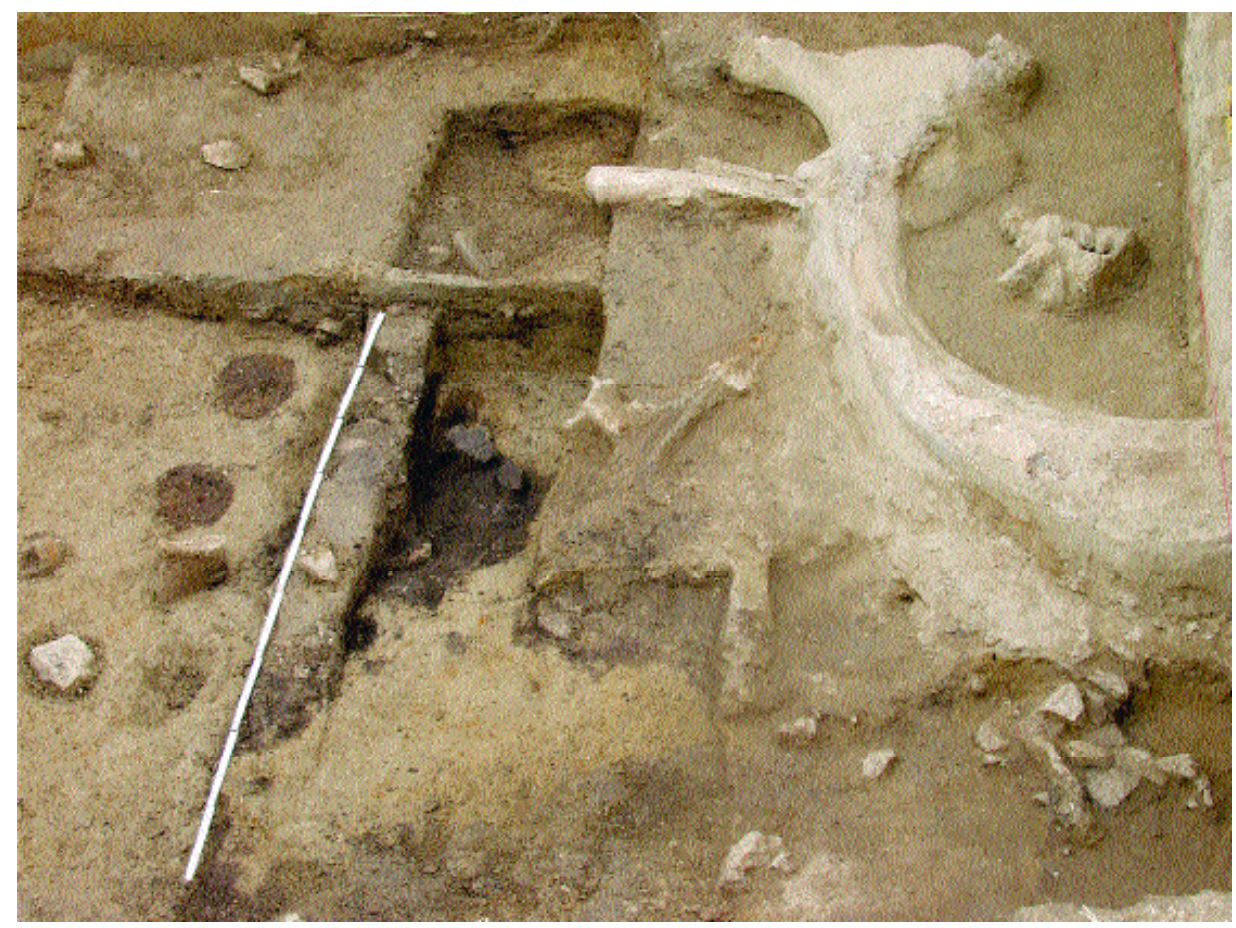

Figure 7 - Pavlov VI, excavation 2007. View of an isolated settlement unit, with central hearth encircled by small boiling pits, and accumulation of mammoth bones (two individuals) aside.

Figure 7 - Pavlov VI, fouilles 2007. Vue d'une unité isolée, avec un foyer au centre entouré par des petites fosses et une accumulation des ossements du mammouth (deux individus) à côté. 
covered in the Olomouc museum, and the original photodocumentation by Matiegka was found at the Department of Anthropology of Charles University. Therefore, a recent anthropological-archaeological project has been focused on description and a new interpretation of this discovery (Velemínská et al. 2004; Svoboda 2005).
Basing on the original field diaries by Maska, supplemented by the published literary references, we created a list of the paleoanthropological finds from Predmostí according their discovery dates and placed them into the spatial context of the site I (fig. 8) and the burial area (fig. 9a,b). One of the main tasks of this study was reconstnction of

\begin{tabular}{|l|l|l|l|l|}
\hline $\begin{array}{l}\text { No of } \\
\text { find }\end{array}$ & Discovered by & $\begin{array}{l}\text { Date of } \\
\text { discovery }\end{array}$ & $\begin{array}{l}\text { More precise } \\
\text { location }\end{array}$ & Characteristics \\
\hline 1. & J. Wankel & 1884 & Chromecek's loam pit & mandible \\
\hline 2. & K.J. Maska & 18.5 .1894 & North & fg. of mandible humerus \\
\hline 3. & K.J. Maska & $7.8 .-10.9 .1894$ & Burial area & skeletons \\
\hline 4. & K.J. Maska & 18.8 .1894 & NW, uncertain & ulna \\
\hline 5. & K.J. Maska & 23.8 .1894 & South & pierced pelvis \\
\hline 6. & K.J. Maska & $24 .-28.8 .1894$ & SE & $\begin{array}{l}\text { mandible, fg. of skull, ulna, radius, } \\
\text { humens, ribs }\end{array}$ \\
\hline 7. & K.J. Maska & 24.8 .1894 & South & fg. of skull, humerus \\
\hline 8. & K.J. Maska & 30.8. & South & rib \\
\hline 9. & K.J. Maska & $4.8 . / 10.9$. & NE & falang, ulna, humerus \\
\hline 10. & M. Kríz & 25.6 .1895 and later & Chromecek-trench VIII & skull, mandible \\
\hline 11. & M. Kríz & 1895 & Chromecek-trench IV & mandible \\
\hline 12. & M. Kríz & 1895 & Chromecek-trench II & two femurs \\
\hline 13. & M. Kríz & 1895 & Dokoupil-trench VII & $\begin{array}{l}\text { fg. of skull, two humeri, } 2 \text { ulnae, } \\
\text { fg. of radius }\end{array}$ \\
\hline 14. & K. Absolon & August 1928, 1930 & & $\begin{array}{l}54 \text { bones of extremities, } 2 \text { teeth, } \\
\text { mandible }\end{array}$ \\
\hline & & & & \\
\hline
\end{tabular}

Table 2 - Review of paleoanthropological discoveries at Predmostí, site la (for spatial distribution, see fig. 8).

Tableau 2 - Inventaire des découvertes paléoanthroloplgiques à Predmostí, site la (pour la répartition spatiale, voir fig. 8).

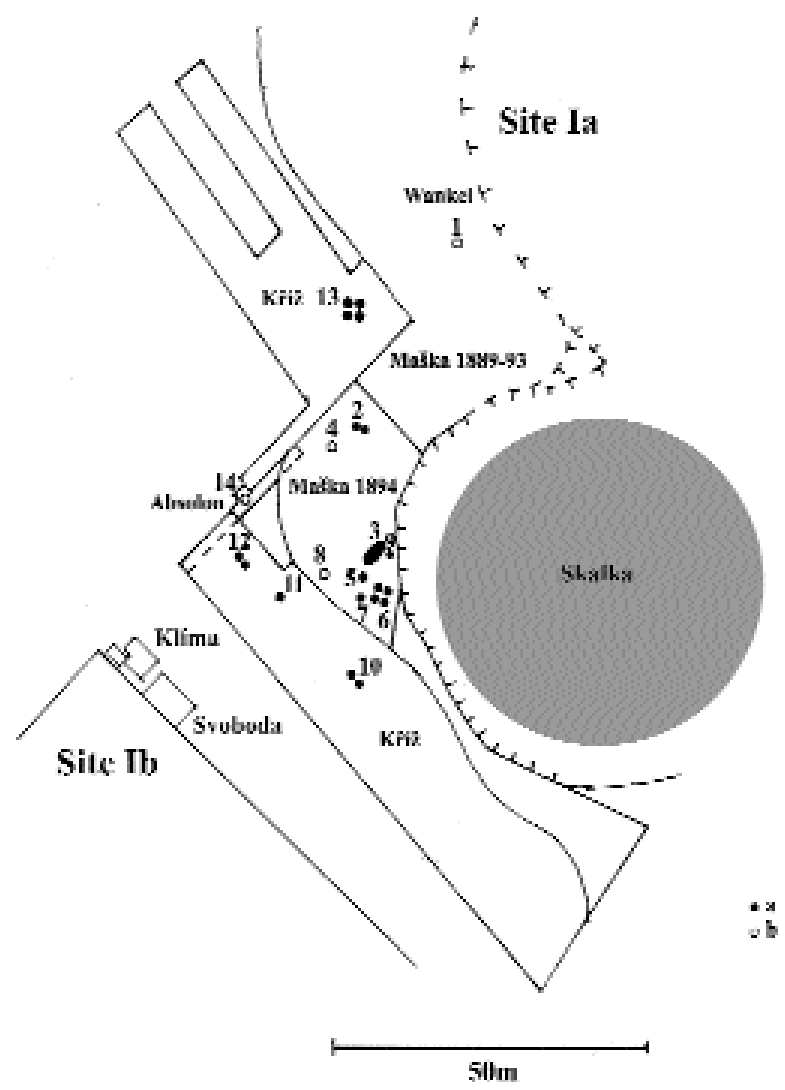

Figure 8 - Spatial distribution of human finds at Predmostí I made by Wankel, Maska, Kríz and Absolon between 18841930. Full oval - the central burial area of 1894; full point solitary find with a relatively certain location; empty point solitary find with generally estimated location.

Figure 8 - Répartition spatiale des restes humains à Predmosti 1 établi par Wankel, Maska, Kríz et Absolon entre 1884 et 1930 : Ovale, zone de sépulture centrale de 1894 ; Point, restes isolés relativement bien localisés ; Cercles, restes isolés avec une localisation estimée. 

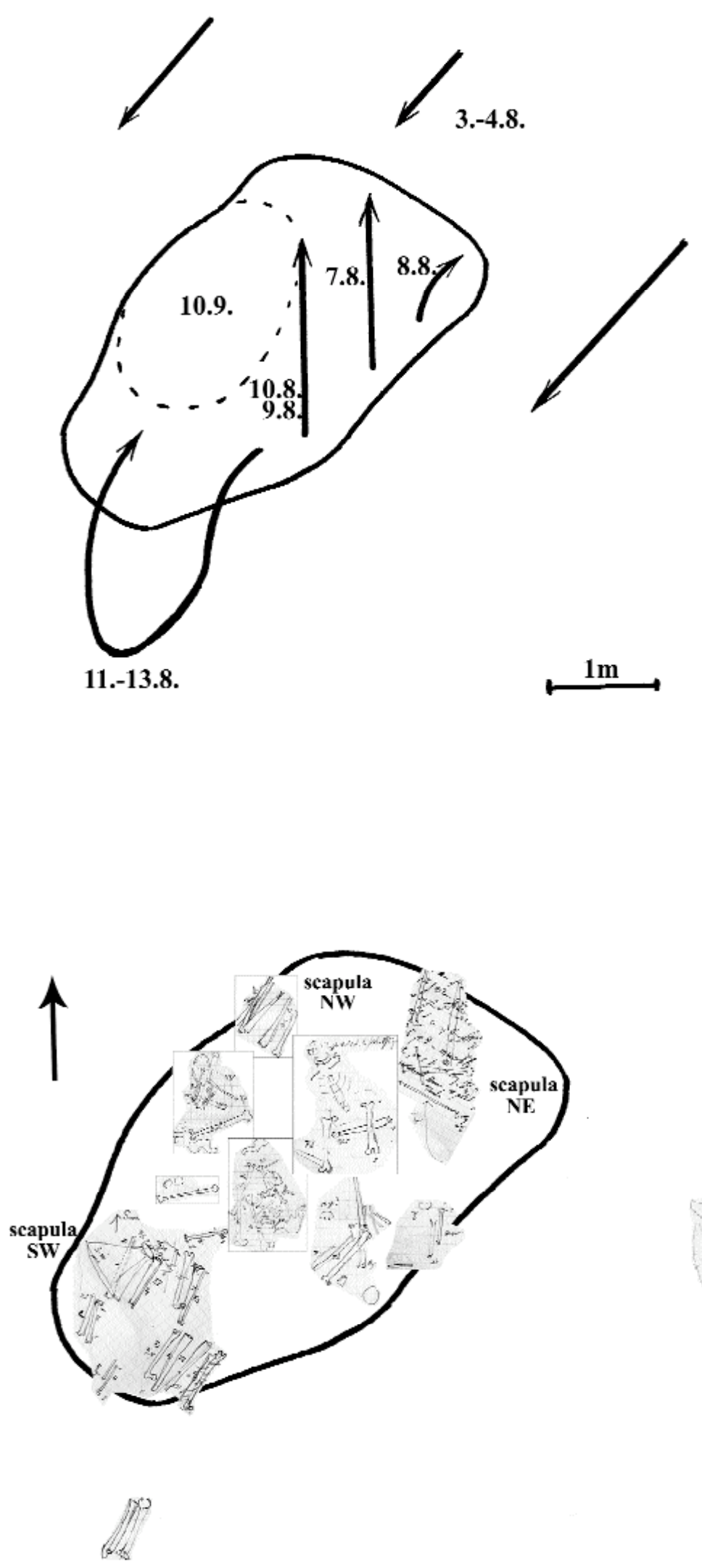

$1 \mathrm{~m}$

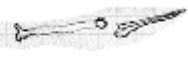

Figure 9a-9b - Predmostíl, reconstruction of the human bone deposit.

Above: Reconstruction of the excavation sequence within the burial area on August 3-13, 1894. Maska approached the area from northeast, on August 7 meets the first human bones, on August 8-10 returns northwards, on August 11-13 continues southwards, whereas some of the important skeletal materials still remain in situ. Below: Reconstruction of the burial area, based on original sketches inserted according to the individual excavation days. The outlines are derived from the sketch on page 40 of the diary. The scapulae are of mammoths.

Figure 9a-9b - Predmostí l, restitution du dépôt des restes humains :

En haut, restitution de la progression des fouilles de la zone funéraire du 8 au 13 août 1894. Maska a abordé cette zone par le nord-est. Le 7 août,il a trouvé les premiers restes humains. Du 8 au 10 août, il a progressé vers le nord, du 11 au 13, il a continué vers le sud alors qu'une quantité importante de vestiges était encore en place.

En bas, restitution de la zone funéraire à partir des croquis originaux des journaux de fouille. Les contours proviennent du croquis de la page 40 du journal de fouille. Les omoplates sont celles des mammouths. 
the movements of Maska within the 1894 area and, in more detail, within the burial area, which adds a spatial dimension to the daily records.

Seen from the viewpoint of the center - periphery relationships inside the large hunter's settlements, we do not consider the burial area at Predmostí, nor the Skalka rock above it, as a real settlement center. Rather, the area seems peripheral, with a lower representation of lithic industry (compared to previously and later excavated parts of the same site), with scattered accumulations of mammoth bones and other faunal remains.

Majority of the skeletons found at this place are only partially preserved, but some, such as Predmostí 3, are remarkably complete, given Matiegka's descriptions. The differential preservation of the individual bones does not prove a pattern of intentional human selection. Therefore, after discussing of a series of aspects and explanations that could have contributed to the formation of such a funeral situation (ethnological parallels, patterns of formation and protection of burials, absence of ochre, additional artifacts, effects of cannibalism or secondary burials), we focused in more detail on the following ones.

All researchers at Predmostí have underlined the role of carnivores in the site formation processes and in disturbance of human skeletal remains. In the photodocumentation, the effect of carnivore gnawing of human bones is not directly observable. However, there is a high ratio of camivores in the associated faunal record, especially whole groups of wolves and foxes. In 1996, we observed fox activites on guanaco carcasses at Tierra del Fuego where at each carcass, foxes created a separate nest to profit from the meat in longerterm, and, as an effect, removing the remains slightly each day. It is possible that the accumulation of fox remains, found at one spot by Maska (on Aug. 7) at the southern margin of the burial area, and elsewhere in the vicinity, could be explained using this analogy.

Maska's records demonstrate the thickness of the deposits in the burial area, composed of loess, humus and charcoal layers, and partly by limestone debris. Because the complexity of these deposits increases towards the former Skalka limestone rock, located a few meters eastwards, I believe that the geological context is influenced by slope removals and accumulation of deposits which one should logically expect at the foot of a larger rock formation.

The mention by Maska that "no skull was found complete, all were fragmented (along the suturas)" may be explained (as at Dolní Vestonice - Pavlov) by pressure of the overlying loess which had accumulated relatively rapidly after the abandonment of the settlement (and, by the same time, after decompositon of the interior soft tissues).

Since the moment of discovery, two competing hypotheses were raised about Predmostí: a contemporary burial as an effect of a catastrophic event, versus gradual accumulation of human bodies. The second altemative offers an additional explanation for the body disturbances because each addition of a new body would affect the previous depositions. So, as an example, the best preserved male skeleton 3 found on Aug. 10 most probably overlay more disturbed bodies below. In addition, some bones display special human activities, as the perforated human pelvis found separately south of the burial.
Most of the bodies were oriented towards the norths, parallel to the original rock wall. Longitudinal axis of the oval-shaped bone deposit concurs with animal bone redepositions as recorded during the 2006 excavation nearby, and with the declination of the original slope.

The burial area yielded only a few artifacts and no ochre. Some of the published mentions of associated decorative objects are due to a later confusion. The only remarkable artifact from the vicinity of the burial area is a half (now completed) of a large, perforated marlstone disc, a type that also accompanied the male burial of Brno 2. In this case, a symbolic interpretation seems plausible.

Mammoth shoulder blades (one with irregular scratches) covered three or more skeletons in the marginal parts of the burial area, but there was no regular nor complete coverage of the whole space. Two more covering shoulder blades were recorded south of this area. Some mammoth bones, erected in the upright position in the vicinity, may also be related to burials (cf. a few human remains below a mammoth mandible, found on Aug. 4). Deposition of the limestone debris layers over the area was natural, however, the limestone blocks were there, and thus also available as coverage of the bodies.

In conclusion, we suspect that the noticeable Skalka rock played a certain role in selecting a burial place at Predmostí. A long-term tendency to deposit dead bodies outside the settlement centers, "below the rock“, could result in this accumulation of human remains at one place, with a pattern of free dispersal around, where they were opened to various postdepositional processes such as camivore activity and the deposition of slope sediments. In 2006, the remaining part of the Predmostí I site, with mammoth bone deposits and artifact scatters, has been excavated and the situation is now preserved under an exhibition pavillon.

\section{Conclusions: notes on the Gravettian settlement dynamics}

By suggesting the possibility of eastern Mediterranean origin for the Gravettian, this paper is certainly far from Europocentric. However, it should be stressed that Europe, as the westernmost Eurasian peninsula, played not only a passive role of recipient of the invading populations, but functioned also as a cradle of new behavioral patterns, technologies, and cultural entities. In this area, the anatomically modern humans created the typical Upper Paleolithic entities such as the Aurignacian and the Gravettian in their complexity. The related archaeological record of the both archeological entities suggests advancement in behavior and lifestyles, be it in selection of a variety of unorganic and organic raw materials, artifact production, hunting, settlement structure, and especially in symbolism and art.

It is evident that the mosaic of Gravettian occupations, after its establishment in Europe, was not a static one, but it displays a dynamic pattern of changes. Westem central Europe and Moravia, where the settlement density and complexity culminates during the earlier Gravettian (Pavlovian, 30-25 ky), provides a reverse picture to that of eastern Central Europe, Eastern Europe and Siberia, where the majority of dates ranges between 25-20 ky (WillendorfiarKostenkian, Siberian Upper Paleolithic). 
Given the strong formal resemblances in form and style among art objects found in long distances, it has been argued that this dynamics reflects certain population shifts from Central to Eastern Europe, and possibly further east. The impuls for these changes is most probably the expansion of Fennoscandinavian glacier and the related climatic deterioration around $20 \mathrm{ky}$ (Last glacial maximum). This climatical boundary terminated the Gravettian occupation on the Middle Danube, where new systems of landscape use and technology were established between 20-15 ky (Kasovian); evidently, it had less effect on settlement and cultural continuity further east.

\section{Acknowledgement}

This paper was prepared as a part of the Czech Grant Agency Project 404/06/0055.

\section{BIBLIOGRAPHIE}

ABSOLON K. 1938 - Die Erforschung der diluvialen Mammutjäger-Station von Unter-Wisternitz in Mähre $n$. Arbeitsbericht über das zweite Jahr 1925. Brünn, 110 pp., XIV tab.

ADOVASIO J.M., SOFFER O., HYLAND D.C. 2005 - Textiles and cordage. In: Pavlov I - Southeast. A window into the Gravettian lifestyles. Dol. Vest. Stud. 14, Brno, p. 432-443.

ANTL W., FLADERER F.A. 2004 - Outlook to the East: The 25 ky BP Gravettian Grub/Kranawetberg campsite (Lower Austria). In: The Gravettian along the Danube. Dol. Vest. Stud. 11, Brno, 116-130.

BÁNESZ L., HROMADA J., DESBROSSE R., MARGERAND I., KOZLOWSKI J.K., SOBCZYK K., PAWLIKOWSKI M. 1992 - Le site de plein air du Paléolithique supérieur de Kasov I en Slovaquie orientale. Slovenská archeológia 40, p. 5-28.

BARTOSÍKOVÁ Z. 2005 - Lithic assemblage of the southeastem periphery (1957, 1970, 1971). In: Pavlov I Southeast. A window into the Gravettian lifestyles. Dol. Vest. Stud. 14, Brno, p. 112-133.

BRÜHL E. 2005 - Bone, antler, and ivory tools. In: Pavlov I - Southeast. A window into the Gravettian lifestyles. Dol. Vest. Stud. 14, Brno, p. 252-293.

CHURCHILL S.E., FORMICOLA V., HOLLIDAY T.W., HOLT B.M., SCHUMANN B.A. 2000 - The Upper Palaeolithic population of Europe in an evolutionary perspective. In: Hunters of the Golden Age. Leiden: University of Leiden, p. 31-57.

DOBOSI V.T. 2000 - Interior parts of the Carpathian Basin between 30,000 and 20,000 bp. In: Hunters of the Golden Age, University of Leiden, p. 231-239.

DOBOSI V.T., ed. 2000 - Bodrogkeresztúr-Henye (NE Hungary) Upper Palaeolithic site. Budapest, Magyar Nemzeti Múzeum, 245 p. ill.
EINWÖGERER T. 2004 - First raw material analysis at the Upper Paleolithic site Krems/Hundsteig (2000-2002) compared to the material of the excavation of Josef Bayer at Krems/Wachtberg (1930). In: The Gravettian along the Danube. Dol. Vest. Stud. 11, Brno, p. 86-99.

EINWÖGERER T., FRIESINGER H., HÄNDEL M., NEUGEBAUER-MARESCH CH., SIMON U., TESCHLERNICOLA M. 2006 - Upper Paleolithic infant burials. Nature 444/16, p. 285.

FLADERER F.A. SALCHER, T. 2004 - Faunal remains from the Krems-Hundsteig/Wachtberg Gravettian site complex - A difference in research techniques and/or site function? In: The Gravettian along the Danube. Dol. Vest. Stud. 11, B mo, p. 100-115.

GARCÍA DIEZ M. 2005a - Decorative patterns on the organic objects. In: Pavlov I - Southeast. A window into the Gravettian lifestyles. Dol. Vest. Stud. 14, Brno, p. 309-373.

GARCÍA DIEZ M. 2005b - Catalogue of worked ceramic pieces. In: Pavlov I - Southeast. A window into the Gravettian lifestyles. Dol. Vest. Stud. 14, Brno, p. 399-414.

GOLOVANOVA L., CLEGHORN N., DORONICHEV V., HOFFECKER J., BURR G., SULERGIZKIY L. 2006 - The Early Upper Paleolithic in the Northem Caucasus (New data from the Mezmaiskaya Cave, 1997 excavation). Eurasian Prehistory 4, p. 43-78.

HAESAERTS P., DAMBLON F., BACHNER M., TRNKA G. 1996 - Revised stratigraphy and chronology of the WIlendorf II sequence, Lower Austria. Archaeologia Austriaca 80, p. 25-42.

HAESAERTS P., BORZIAK I., CHIRICA V., DAMBLON F., KOULAKOVSKA L. 2004 - Cadre stratigraphique et chronologique du gravettien en Europe Centrale. In: The Gravettian along the Danube. Dol. Vest. Stud. 11, Brno, p. 33-56.

HLADILOVÁ S. 2005 - Tertiary fossils, especially molluscs. In: Pavlov I - Southeast. A window into the Gravettian lifestyles. Dol. Vest. Stud. 14, Brno, p. 374-390.

HOLLIDAY T.W. 1997 - Body proportions in Late Pleistocene Europe and modern human origins. Joumal of Human Evolution 32, p. 423-447.

JÖRIS O., WENINGER B. 2004 - Coping with the cold: On the climatic context of the Moravian Mid Upper Palaeolithic. In: The Gravettian along the Danube. Dol. Vest. Stud. 11, Brno, p. 57-70.

KAMINSKÁ L., TOMÁSKOVÁ S. 2004 - Time space systematics of Gravettian finds from Cejkov I. In: The Gravettian along the Danube. Dol. Vest. Stud. 11, Brno, p. 186-216.

KLÍMA B. 1991 - Das paläolithische Massengrab von Predmostí, Versuch einer Rekonstruktion. Quartär 41/42, p. 187-194. 
KLíMA B. 1995 - Dolní Vestonice II. Ein Mammutjägerplatz und seine Bestattungen. ERAUL 73/Dol.Vest.stud. 3, 183 p. ill.

KLÍMA B. 1997 - Bone Industry, Decorative Objects, and Art - Knochenindustrie, Zier- und Kunstgegenstände. In: Pavlov I-Northwest. Dol.Vest.stud. 4, p. 227-286.

KLÍMA B. 2005 - Excavation at Pavlov I, 1954 and 1956. In: Pavlov I - Southeast. Awindow into the Gravettian lifestyles. Dol. Vest. Stud. 14, Brno, p. 17-24.

KLÍMA B., KUKLA J., LOZEK V. A de VRIES, H. 1962 Stratigraphie des Pleistozäns und Alter des paläolithischen Rastplatzes in der Ziegelei von Dolní Vestonice (Unter-Wistemitz). Anthropozoikum 11, p. 93-145.

KOVACIC V., GRABMÜLLEROVÁ J., BAJZÍK, V. 2005 Photographic evidence of the textile imprints. In: Pavlov I Southeast. A window into the Gravettian lifestyles. Dol. Vest. Stud. 14, Brno, p. 444-448.

KOZLOWSKI J.K. 1986 - The Gravettian in Central and Eastern Europe. In: Advances in world archaeology 5, p. 131-200.

KRÁLÍK M., NOVOTNY V. 2005 - Dermatoglyphics of ancient ceramics (paleodermatoglyphics). Analysis of fingerprints from Pavlov. In: Pavlov I - Southeast. A window into the Gravettian lifestyles. Dol. Vest. Stud. 14, Brno, p. 449-497.

MASON S., HATHER J., HILLMAN G. 1994 - Preliminary investigation of the plant macro-remains from Dolni Vestonice II and its implications for the role of plant foods in Palaeolithic and Mesolithic Europe.Antiquity 68, p. 48-57.

MUSIL R. 2005 - Animal prey from the research areas 1954 and 1956. In: Pavlov I - Southeast. A window into the Gravettian lifestyles. Dol. Vest. Stud. 14, Brno, p. 190-228.

NEUGEBAUER-MARESCH Ch. 1999 - Le Paléolithique en Autriche. Jerôme Millon, Grenoble, 202 p. ill.

NIGST P.R. 2004 - Some preliminaryobservations on intrasite spatial patterning of Grub/Kranawetberg (1995 and 1996 area). In: The Gravettian along the Danube. Dol. Vest. Stud. 11, Brno, p. 131-141.

NOVÁK M. 2004 - Gravettian occupation in the lower layer of Kasov I. In: The Gravettian along the Danube. Dol. Vest. Stud. 11, Brno, p. 217-242.

NOVÁK M. 2005 - Pavlov I - Southeast: Review of spatial distributions. A window into the Gravettian lifestyles. Dol. Vest. Stud. 14, Brno, p. 53-71.

NYVLTOVÁ FISÁKOVÁ M. 2005 - Animal bones selected for tools and decorations. In: Pavlov I - Southeast. A window into the Gravettian lifestyles. Dol. Vest. Stud. 14, Brno, p. 247-251.

NYVLTOVÁ FISÁKOVÁ M. 2007 - Seasonality of gravettian sites based on study of mammal's dental cement microstructures. Prehleld Vyzkumu 48, 13.23.
OLIVA M. 2000 - Some thoughts on Pavlovian adaptations and their alternatives. In: Hunters of the Golden Age, University of Leiden, p. 219-229.

OLIVA M. 2001 - Les pratiques funéraires dans le pavlovien morave: Révision critique. PréhistoireEuropéene 16$17,191-214$

OTTE M., NOIRET P. 2004 - Évolution du gravettien au Moyen Danube. In: The Gravettian along the Danube. Dol. Vest. Stud. 11, Brno, p. 8-32.

PEARSON O.M. 2000 - Activity, climate, and postcranial robusticity. Current Anthropology 41, p. 569-607.

PETTITT P., TRINKAUS E. 2000 - Direct radiocarbon dating of the Brno 2 Gravettian burial. Anthropologie 38, 149-150.

ROEBROEKS W., MUSSI M., SVOBODA J., FENNEMA K. 2000 - Hunters of the Golden Age. The Mid Upper Palaeolithic of Eurasia 30,000 - 20,000 BP. Leiden, University of Leiden, 410 p. ill.

SAJNEROVÁ A. 2005 - Use-wear analysis of the lithics. In: Pavlov I - Southeast. Awindow into the Gravettian lifestyles. Dol. Vest. Stud. 14, Brno, p. 134-148.

SKRDLA P. 1997 - Pavlovian lithic technologies. In Pavlov I-Northwest. Dol.Vest.stud. 4, p. 313-372.

SKRDLA P., ed. 2005 - The Upper Paleolithic on the middle course of the Morava river. Dol. Vest. Stud. 13, Bmo, Institute of Archaeology.

SOFFER O., ADOVASIO J.M. 2004 - Textiles and Upper Paleolithic lives. A focus on the perishable and the invisible. In: The Gravettian along the Danube. Dol. Vest. Stud. 11, Brno, p. 270-282.

SOFFER O., VANDIVER P. 2005 - Ceramic fragments. In: Pavlov I - Southeast. Awindow into the Gravettian lifestyles. Dol. Vest. Stud. 14, Brno, p. 415-431.

SOFFER O., VANDIVER P., KLÍMA B., SVOBODA J. 1993 - The pyrotechnology of performance art: Moravian venuses and wolverines. In: H.Knecht et al. (eds.), Before Lascaux. Boca Raton: CRC Press, p. 259-275.

STEGUWEIT L. 2005 - Gebrauchsmuster an "ElfenbeinZylinder" aus jungpaläolithischen Fundstellen in Niederöstemeich und Mähren. Mitt. Komm. Quartärforsch. Österr. Akad. Wiss. 14, 177-193.

SVOBODA J., ed. 1994 - Pavlov I, Excavations 1952-53. ERAUL 66/Dol.Vest.Stud. 2, Liege-Brno, 234 p. ill.

SVOBODA J., ed. 1997 - Pavlov I - Northwest. The Upper Paleolithic burial and its settlement context. Dol.Vest. Stud. 4, Brno, Institute of Archaeology, 472 p. ill. 
SVOBODA J. 2003a - Gravettian and Epigravettian chronologies in the Middle Danube area. In: $F$. Widemann, Y. Taborin, eds., Chronologies géophysiques et archéologiques du paléolithique supérieur, Bari, p. 273-282.

SVOBODA J. 2003b - The Gravettian of Moravia: Landscape, settlement, and dwellings. In: S.A. Vasil'ev, $O$. Soffer, J. Kozlowski, eds., Perceived Landscapes and Built Environments, British Archaeological Reports Intemational Series 1122, Oxford, p. 121-129.

SVOBODA J.A. 2004 - Afterwords: The Pavlovian as a part of the Gravettian mosain. In: The Gravettian along the Danube. Dol. Vest. Stud. 11, Brno, p. 283-297.

SVOBODA J.A., ed. 2005 - Pavlov I - Southeast. A window into the Gravettian lifestyles. Dol. Vest. Stud. 14, Bmo, Institute of Archaeology, 500 p. ill.

SVOBODA J.A. 2005 - Predmostí. The context of paleoanthropological discoveries. Prehled vyzkumu 46, 63-91.

SVOBODA J.A. 2007 - On modern human penetration into Northern Eurasia: the multiple advances hypothesis. In: P. Mellars, K. Boyle, O. Bar Yosef, Ch. Stringer, eds., Rethinking the Human Revolution, Cambridge, p. 329-339.

SVOBODA J.A., NOVÁK M. 2004 - Eastern Central E u rope after the Upper Pleniglacial: Changing points of observation. Archäologisches Korrespondenzblatt 34, p. $463-477$.

SVOBODA J.A., SEDLÁCKOVÁ L., eds., 2004 - The Gravettian along the Danube. Dol. Vest. Stud. 11, Bmo, Institute of Archaeology, 297 p. ill.

SVOBODA J., LOZEK V., VLCEK E. 1996 - Hunters between East and West. The Paleolithic of Moravia. New York - London: Plenum, 307 p. ill.

SVOBODA J., KLÍMA B., JAROSOVÁL., SKRDLA, P. 2000 - The Gravettian in Moravia: Climate, behaviour and technological complexity. In: Hunters of the Golden Age, University of Leiden, p. 198-217.

SVOBODA J.A., van der PLICHT J., KUZELKA V. 2002 Upper Palaeolithic and Mesolithic human fossils from Moravia and Bohemia (Czech Republic): some new C14 dates. Antiquity 76, p. 957-962.

TERBERGER T. 2003 - Vom Gravettien zum Magdalénien in Mitteleuropa - Aspekte der menschlichen Besiedlungsgeschichte in der Zeit um das zweite Kältemaximum der letzten Eiszeit. Archäologisches Nachrichtenblatt 8, p. 55-62.

TERBERGER T., STREET M. 2002 - Hiatus or continuity? New results for the question of pleniglacial settlement in Central Europe. Antiquity 76, p. 691-698.
TESCHLER-NICOLA ed. 2006 - Early Modern Humans at the Moravian Gate: The Mladec caves and their remains. Springer, Wien - New York.

TESCHLER-NICOLA M., TRINKAUS E. 2001 - Human remains from the Austrian Gravettian: The Willendorf femoral diaphysis and mandibular symphysis. Joumal of Human Evolution 40, p. 451-465.

TRINKAUS, E., SVOBODA, J.A., eds., 2006 - Early Modern Human evolution in Central Europe: The people of Dolni Vestonice and Pavlov. Dol. Vest. Stud. 12. New York, Oxford University Press.

TRINKAUS E., SVOBODA, J., WEST, D.L., SLÁDEK, V., HILLSON, S.W., DROZDOVÁ, E., FISÁKOVÁ, M. 2000 Human remains from the Moravian Gravettian: Morphology and taphonomy of isolated elements from the Dolní Vestonice II site. Journal of Archaeological Science 27, p. 1115-1132.

TSANOVA T. 2006 - Les débuts du Paléolithique supérieur dans l'st des Balkans. Réflexions à partir des études taphonomiques et techno-économiques des ensembles lithiques des sites Bacho Kiro (couche 11), Temnata (couche VI et couche 4) et Kozarnika (niveau VII). Thèse, Université Bordeaux 1.

VALOCH K. 1996 - Le Paléolithique en Tchéquie et en Slovaquie. Préhistoire d'Europe 3. Jerôme Millon, Grenoble, 205 p., 130 ill., 8 cartes.

VELEMÍNSKÁ J., BRUZEK J., VELEMÍNSKY P., SEFCÁKOVÁ A., KATINA S. 2004 - The use of recently rediscovered glass plate photodocumentation of those human fossil finds from Predmostí u Prerova destroyed during World War II. Casopis Národního Muzea, rada prír. 173 , p. $129-132$

VERPOORTE A. 2001 - Places of art, traces of fire. Archaeological Studies Leiden University 8/Dol. Vest. Stud. 6, Leiden, 141 p. ill.

VERPOORTE A. 2002 - Radiocarbon dating the Upper Paleolithic of Slovakia: Results, problems and prospects. Archäologisches Korrespondenzblatt 32, 311-325.

VERPOORTE A. 2005 - Lithic assemblage of Pavlov I South-Central (1954, 1956, 1963, 1964). In: Pavlov I Southeast. A window into the Gravettian lifestyles. Dol. Vest. Stud. 14, Brno, p. 75-111.

VLCEK E. 1991 - Die Mammutjäger von Dolní Vestonice. Archäologie und Museum Heft 022. Liestal, 136 p. ill.

WEST D. 1996 - Horse hunting, processing and transport in the Middle Danube. In: Paleolithic in the Middle Danube region. Brno, Inst. of Archaeology, p. 209-245.

WOJTAL P., SEDLÁCKOVÁ L., WILCZYNSKI J. 2005 Human activities on the faunal material. In: Pavlov I - 
Southeast. A window into the Gravettian lifestyles. Dol. Vest. Stud. 14, Brno, p. 229-246.
ZELINKOVA M. 2007 - Bone and antler industry from Dolni Vestonice I. Acta Musei Moraviae, Sci. soc. 92, 9-51. 